POLYANSKAALLA,

Doctor of Economics, Professor,

Ivano-Frankivsk National Technical University of Oil and Gas,

Institute of Petroleum Economics and Management

\title{
PRINCIPLES OF INTERNATIONAL PARTNERSHIP IN THE DEVELOPMENT OF DOMESTIC ENTERPRISES
}

\begin{abstract}
In the article the nature, characteristics and role of international partnership in the development of domestic enterprises in the context of globalization are researched, special attention is paid to the formation of partnerships in gas industry. The importance of principles of international enterprises in the development of gas industry is determined on the basis of their priority evaluation in industry. The research allows to justify strengthening and expanding of international cooperation potential on the basis of international partnership principles implementation.
\end{abstract}

Keywords: international partnerships; principles; gas industry; globalization.

\section{Introduction}

The relevance of research issues, related to globalization, is determined by such trends as: the growth of transnational production, the flow of foreign investment and capital, economic relations in questions of energy supply, energy security, and informatization of all areas of economics and other important problems.

The growth of all globalization describes the activation of foreign activity, which is impossible without the agreement among companies and countries in the issues of mutually beneficial cooperation and partnership. The formation of international economic relations on the basis of partnership relations among businesses, government, organizations, institutions, regardless of their ownership, organizational and legal structure and level of management, allows to maximize the usage of technical and technological, market, financial and investment opportunities in order to achieve mutually beneficial joint purposes, and in condition of effective management to achieve synergistic effect of cooperation. However, in Ukraine the formation of scientific principles of partnership relations requires deep studies, taking into account international experience and national peculiarities. So, for today it is important to research the question of partnership principles in order to create the civilized, equal, mutually beneficial preconditions for international cooperation for solving modern challenges of development in the context of globalization, especially in energy sector.

Analysis of recent researches and publications

The problem of development in globalization conditions is widely studied by leading domestic and foreign scientists, including Z. Brzezinski (2016), Z. Bauman (2008), O. Bilorus (2010), D. Lukyanenko (2013), V. Voronkova (2009). Despite positive and negative effects of this phenomenon it provides the development of effective methods of entry, operation and interaction among enterprises on the international level, as well as mechanisms of harmonization of economic, social and political interests of different countries, organizations and associations in solving problems that require joint efforts. So the category of international partnership in context of globalization deserves special attention.
In everyday life the concept of partnership is associated with the exchange, cooperation, mutual benefits and agreement - activities, that we can associate with the expression of Adam Smith in his famous work "The Wealth of Nations": "Give me what I want and you will have what you want.... ". But in life there are many situations where the idea of joint activity fails. According to the viewpoints of local experts in Ukraine there are about 300 startups every year but only a few dozens of entrepreneurs survive. Because of such a situation, the inability to negotiate with each other due to the principles of partnership is stated (l. Kenigshteyn).

Normative foundations of International Partnerships are widely presented in international and domestic legislation, which draw attention to the actuality of international partnerships development, particularly in energy sector, and outline the perspective activities in this way.

Practical aspects of international partnership, based on studies of integrated logistics systems, are considered in the works of E. Krykavskiy, N. Chornopyskoyi (2012, 2013), N. Chukhrai (2008). Some issues of the international component in reforming domestic enterprises, especially in domestic energy sector, are researched in the works of V. Khaustova (2015), O. Dzoba (2012) G. Zachmann, D. Naumenko (2014) and others.

Previously unsolved problems

It should be noted that the issues of international partnership in the context of globalization are researched in different terms, covering particular areas of international activities and the nature and significance of globalization for the development of different sectors of the Ukrainian economy, as well as the formation of partnerships normative base, taking into account the advantages and disadvantages of integration into the global economy.

However, it is important to determine how partnership principles practically determine the development level in energy sector. Moreover, partnership principles, used in industry on the level of an enterprise or in the national economy, require additional principles of international cooperation, international trade, organization of activity taking into account the integration process and globalization effects. Conceptual vision of energy sector develop- 
ment, based on market management principles, is worthy of mentioning.

\section{Main purpose of the article}

The purpose of the article is to research the principles of international partnership in the development of domestic enterprises in the context of globalization on the basis of activity in energy sector through the consideration of organizational, normative and legislation, commercial as well as conceptual aspects of partnership maintenance in order to research their relations, mutual impact, and importance for the establishment of market-oriented energy sector.

\section{Research methods}

Research methodology includes, in particular, analysis and synthesis methods which regulate basic concepts of highlighted principles; system-functional method examines the processes of forming group conditions of partnership activity through the particular principles; generalization method in this article is used to estimate the state of partnership principles performance and to identify areas of improving the activity in energy sector; content analysis researches regulations in international activities, method of priority choice in using paired comparisons helps outline actual directions of enterprises performance in gas sector.

\section{Results and discussions}

Globalization processes have impact on different areas. Energy sector is strategically important for Ukraine. Formation of competitive energy sector in the world economy is complicated with obstacles in current economic and political situation in the country and a number of objective factors, such as irregularity of energy resources location, activation of energy resource trade, enhanced competition in the world oil, gas, and coal markets, changes in the institutional structure of energy markets. Besides that, as far as many countries in the world don't have a sufficient amount of their own energy resources, current trends of globalization tend to move to the principle of collective energy security instead of dominant ideas of national energy independence in the past. This brings new principles of management in energy sector, in particular gas sector: energy efficiency improvement; energy security enhancement; formation of energy market and creation of regulatory structure; elimination of subsidies and price disproportion; transparency and responsibility; adaptation programs of EU energy policy.

As partnership principles we consider rules, directions, recommendations which might be used for supporting international activity. Relevance of partnership principles research for today is determined as one of major challenges of oil and gas sector in order to coordinate the activity not only of its basic units that perform basic functions, but also partners who serve or support the activities of industrial enterprises. Integration as a basic principle of partnership cannot be isolated from other processes and phenomena at enterprises, so it is important to understand what obstacles may arise and what benefits and disadvantages of the integration process are today on energy market.

In practice, barriers can arise from: organizational structure, performance of estimate system, inventory management, information technology and operation experience in enterprise system for knowledge exchange.

In such circumstances, there is a need to harmonize the principles of cooperation in integrated value chains by organizing the following activities:

- the internal integration through the usage of the following ways of organizing cooperation among enterprises:

1) cooperation agreements on the basis of informal enterprises may take the form of procurement of goods for discounts on substantial purchases; combination of cargo for transportation to reduce transportation costs; approval of packaging sizes to facilitate cargo handling; usage of general lists of the best suppliers. The advantages of cooperation under informal agreements are flexibility and lack of commitment. The disadvantages are that each side may terminate cooperation without notice at any convenient time;

2) collaboration based on formal agreements among enterprises which is realized on the basis of written contracts, what sets an obligation of each side to supply. The advantage is a detailed indication of the characteristics of cooperation so that each side knows exactly what to do. Disadvantages include the loss of flexibility and the need to work in more rigid conditions;

3 ) the formation of strategic alliance or partnership. The basis of such alliances is mutually beneficial collaboration in the past and confidence in the long-term obligations of the sides. Guaranteed stability motivates businesses to invest in the improvement of their products and operations. Public-private partnership plays an important role in this activity;

4) vertical integration rate, which indicates the extent to which the activity is integrated into one organization. This can manifest itself in the following ways:

- takeover of another company that allows to some extent affect the operations, although not necessarily to control them; joint ventures; purchase of an organization that is the most common option for external integration;

- expansion of international cooperation which requires to bring existing facilities with the requirements of international activities. In particular, while estimating the potential of industrial enterprises in the context of the integration process, it should be noted that their status as a functional link of supply chain does not always meet the criteria of integration, such as: stock component indicators (deterioration of assets, the ratio of fixed assets renewal and disposal coefficients, capital productivity) are low, so there is a need in new capital assets and improvement of their usage; resource estimate component (energy and resource efficiency indicators of capital goods) says about the need to maintain more efficient usage of available resources.

The partnership has a number of advantages and disadvantages, and for more profound realization of the potential of this cooperation method, it is important to consider a number of recommendations from national and foreign experts summarized in partnership principles at the level of companies, such as: the creation of common vision and mission of cooperation; the discussion of mutual needs and expectations as well as opportunities to achieve them; the identification and usage of strengths and capabilities of each partner; the existence of clear agreements during decision making, as well as rules, regulations and restrictions; the establishment of common and individual goals; early detection of discrepancies, deviations, disappointments to prevent conflicts and disputes; the division of responsibility among the partners in business and in relation to each other; the availability of clear rules out of business.

Taking into account the complexity of partnership relations, diversity and specificity of partners' performance in various spheres of social life, the principles of international partnership should be considered in terms of organizational, normative commercial and conceptual components, each of which fulfils specific tasks of joint activities, including: organizational principles - forming conditions of community performance; normative and legislative principles - reinforcing legal basis for building 
partnership relations and distribution of mutual responsibilities and obligations; commercial principles - defining the conditions of collaboration and economic benefits from such performance; conceptual principles - taking into account basis requirement of strategic goals achievement (Fig. 1).

Meeting these requirements needs an integrated approach since it does not only depend on decisions which are made by business leaders in the areas of production, supply, transportation, storage and distribution of energy resources, but also on the decisions made on the meso, macro and mega levels of management. The connecting idea of such relations is international partnership, because in terms of integration into the global space, the ability to negotiate becomes one of the key success factors of solving important modern development tasks.

Summarizing the existing approaches to the category of the international partnership, according to the principles of this performance, we mean general provisions that reflect defining characteristics, requirements, criteria which ensure optimal functioning of a country, region, individual business, without which they cannot properly fulfill mutual obligations, liabilities and agreements as well as take into account mutual interests and achieve common goals, performing internationally.

As the supply chain in energy sector is one of the ways to integrate different areas of activity in order to solve common energy problems, it is offered to consider forms, principles and international partnerships peculiarities through the research of energy resources moving manage- ment processes, including gas, within the supply chain of this resource. Close coordination among various functional areas of activity that ensures the production, transmission, distribution and supply of strategically important for Ukraine resources, requires the integration of logistics operations and their respective control within the formed logistics system. Actually, constructing logistics supply chain in a liberalized market of energy resources and the formation of competitive relations in it which are connected not only with the national, but also with international partner organizations will allow to integrate functional performance of gas industry into the international segregation of labor.

The principle of added value will create the competitive advantage by improving the quality of products and services produced in these areas, and the principle of integration as dynamic, multinational process of joint performance will promote more effective involvement of all stakeholders in different fields of society to solve various issues, challenges and problems, as well as accumulation of valuable cooperation experience.

Preconditions of applying this model for gas market of Ukraine are laid in the Law of Ukraine "About the Principles of Natural Gas Market Operation". Implementation of the law not only promotes the integration of Ukraine into European gas market, but also helps build an equal and mutually beneficial relationship with its subjects on market principles, and create a basis for the formation of national competitive gas market at the level of world developed countries.

It should be noted that currently fragmented conside-

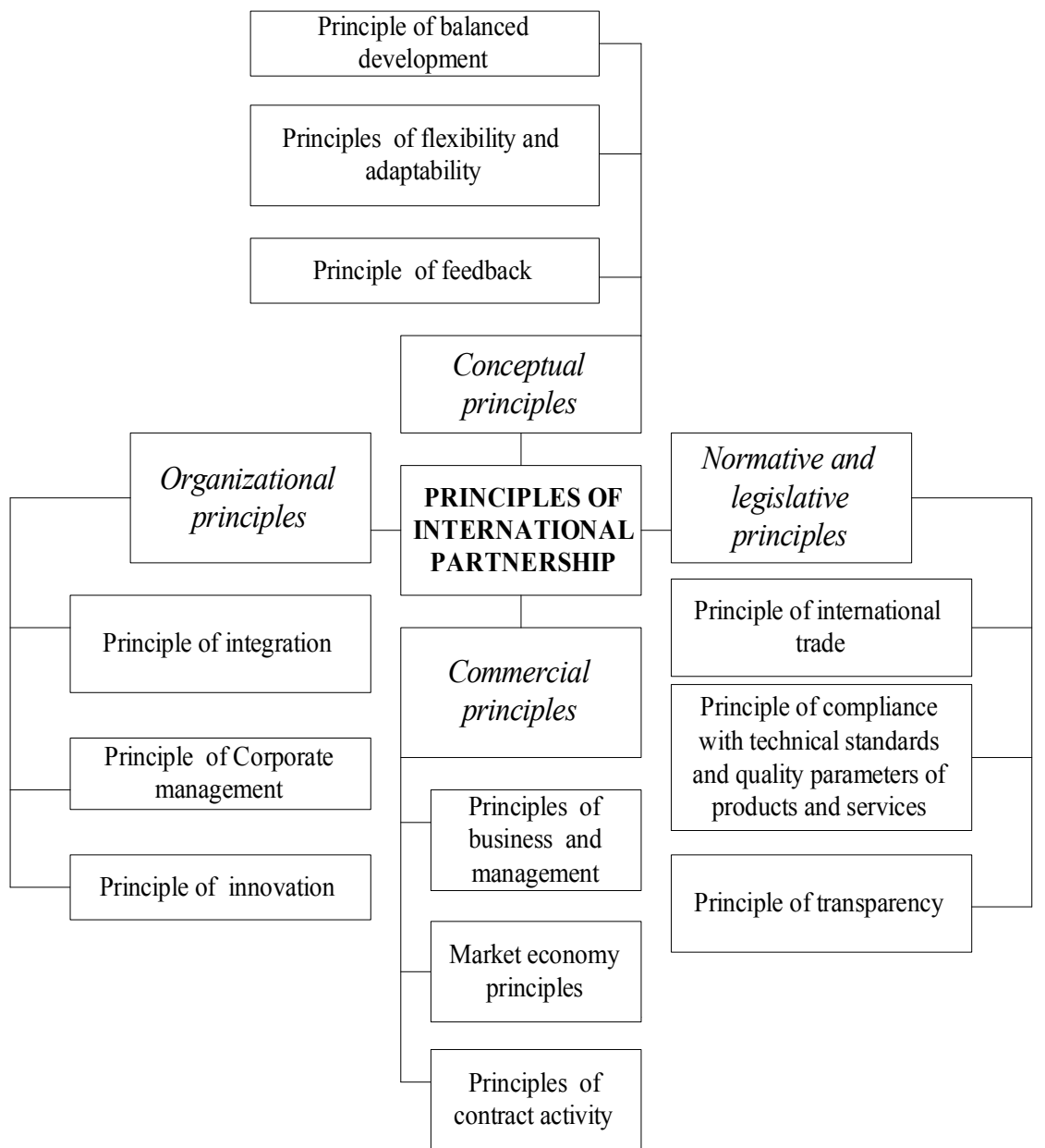

Fig. 1. The principles of partnership in gas sector

Source: author's model. 
ration of gas transportation, storage, supply and distribution functions significantly limit the potential of international partnerships in industry. The changes declared in the Law mentioned above create preconditions for strategic raw materials movement on the basis of the integration principle. Managing integrated resources flow in energy supplies chain can be represented on the basis of the selection of three levels of its members interaction and collaboration: the level of internal integration within the activity of industrial enterprises; the level of intersectoral and interregional interaction with the usage of modern methods of partnership and cooperation between enterprises in gas supply chain; the level of international partnership and cooperation, that requires the alignment of criteria and parameters of logistics management according to the international standards. At each level of raw materials flow management must take into account the principles of competitive energy market regulation, namely: the separation of activities to introduce competition wherever it is possible; freedom of access and investment in competitive activities; freedom of agreements and competitive pricing; access to networks and infrastructure; supervision by an independent regulator; adapting to the usage of information technologies; diversification of energy sources supply; energy partnerships with producers, transit countries and other international participants.

The potential of partnership strengthening is provided by organizational component of management during the construction of logistics management systems. This process is based on the principles which ensure continuous improvement and strategic flexibility of logistics solutions acceptance in international partnerships, including (Krykavskiy E., Chornopyska N., 2012): holism as the ability of a system to ensure the integrity and ability to be transparent without limits in the process of its components integration into the environment; sequence as the ability to consistently generate internal structure and system communications with the external environment, ensuring the elimination or avoidance of "bottlenecks" and goals conflict; compatibility as the characteristics of subsystems' consistency on the basis of creating or isolating relevant characteristics, which reduces system internal tension and frees up capacity to respond to external influence, ensuring the stability of a system; complementary as the ability to expand or supplement that does not require significant additional spending of time and money.

Achieving sustainable partnership relations depends on whether partners are ready to cooperate and collaborate in solving joint problems, taking into account both their own interests and the interests of other partners. For example, the company "Naftogaz" has developed basic principles of interaction with stakeholders, including employees, group enterprises, partners, media, competitors, government and Ukrainian society. The company interacts with business partners on the basis of long-term cooperation, mutual benefit, respect, trust and fairness, objectivity as well as common principles of partnership (NJSC "NaftoGas", 2014).

Formed partnership relations require appropriate management. The intensity and duration of the relationship as well as the presence of collective experience are accompanied by compliance with the principle of relations quality, performance stability and flexibility. Reliable, longterm relationships and significant collective experience enables partners to plan their activities more easily, to adapt to each other and to the environment in which they operate as well as to identify and quickly eliminate deficiencies (Chukhrai N., 2008). These principles should be supplemented with the principle of adaptability as the ability to adapt to changes, to respond flexibly on changes in the environment. The principle of sustainability ensures the stability of a system and achievement of common goals; the principle of humanization of functions and technological decisions allows the compliance with ecological, ergonomic, social requirements as well as ethical requirements of staff.

Today the development of the national fuel and energy complex of Ukraine is largely dependent on international policies concerning Ukraine by western and eastern neighboring countries. Russia's policy of gas supply in Ukraine has shown the strong desire of not only economic but also political influence on the development of Ukraine. The West, declaring concern over events which take place in Ukraine, would like to have politically independent and economically stable transit country of energy resources from the East to the West. In its effort the West tries to help Ukraine, and as example of such cooperation there is the organization of reverse gas supplies to Ukraine.

Of course, searching of diversified energy supply sources is an important step towards increasing the economic and political security of Ukraine, taking into account the fact that recently more than half of imported Ukrainian gas has been supplied from Russia. Performance in this direction should be continued because experts notice that decisions in energy supply sphere should ensure gas imports to Ukraine from one source which don't exceed one third, i.e. $15-20 \mathrm{bln} . \mathrm{m}^{3}$, and taking into account transit fees for Russian gas - this is $10-15$ billion $\mathrm{m}^{3}$. Today deficit of gas in Ukraine is provided with physical reverse flows of natural gas that is related to import from the West. Reverse gas flows to Ukraine are directed from Poland, Slovakia, Hungary, and Norway.

In conditions of gas deficit, one of the important challenges facing energy industry is to increase domestic gas production by: extraction from existing fields using new technologies; increasing production in shallow and deep-sea gas fields; increasing gas production by using resources of shale gas; production of coal bed methane. The Department US Energy Information put Ukraine on the 4th place in Europe for estimated reserves of shale gas in the amount of 3.6 trillion cubic meters after Russia, Poland and France (Zachmann G., Naumenko D., 2014). According to average estimates, given in the Updated Energy Strategy 2030, technically available reserves of shale gas in Ukraine are situated within limits from 1 to 1.5 trillion $\mathrm{m}^{3}$. The signature of production distribution agreement in the extraction of hydrocarbons with the American company "Chevron Ukraine BV" in Olesko became practical step towards the development of international partnership.

While estimating the potential of gas industry in the context of international cooperation, it should be noted that domestic gas storage capacity is a significant part of it. It provides strategic reserve of natural gas for the case of emergency. The perspective direction of underground gas storage development in Ukraine and the subject of future research is the estimate of opportunities to provide services with the usage of their free capacities for European companies. In this framework, the decisions would be taken in the creation of East European Gas Hub on the basis of Ukrainian underground storage facilities, located on the western border and involving operating companies of gas transport systems of Poland, Hungary and Slovakia.

Thus, future development of the domestic energy sector is associated with the expansion of international collaboration and cooperation. This requires bringing existing facilities up to international standards. Today the level and characteristics of development impose significant limi- 
tations on the integration possibilities of Ukraine. In particular, technical conditions of underground gas storage don't correspond to the requirements for their operation. According to the Association Agreement EU-Ukraine, Ukrainian enterprises have to implement about 20 thousand European technical standards and regulations. One of the ways to eliminate technical barriers is taking into account the experience of technical regulation in the EU which provides good results. According to this experience, basic requirements are connected with safety and quality of products. The compliance with requirements, which are stipulated with technical regulation, is implemented due to market supervision, not to the production process control. Despite these limiting factors, the development of partnership relations puts before domestic enterprises the requirement of compliance with international quality standards throughout energy resources supply chain both within the national economy and in the framework of international cooperation.

It should be noted that the directions and perspectives of international partnerships are defined in the basic document of energy industry - the Energy Strategy. In this strategic program document, international and national organizations are expected to unite their efforts to make changes in the domestic energy sector. Their performance is related to the creation, dissemination and compliance with the principles of international partnership and lie in the legislation sphere of energy sector regulation on micro, macro and mega levels.

The result of international partnership in energy sector may be the development of relevant partnership policy. Consistent and agreed partnership policy, based on the consideration and respect of basic partnership principles as well as their effective implementation, leads to unification of partnership general requirements. And partnership principles, laid in the international legislation, harmonize international relations according to mutual values, laws, principles, such as democratic principles and human rights, market economy principles, principle of market economic reforms and free trade area formation between the sides of the agreement; principle of the amendment in view of changes in circumstances (Green book, 2006).

For domestic enterprises, gaining international partners' confidence is based on the implementation of the transparency principle. As practice shows, transparent performance of some domestic enterprises remains low. In particular, in energy sector, the results of surveys of 120 oil and gas companies, engaged in economic perfor- mance, related to oil and gas production and transportation at the territory of Ukraine, which were declared in the Income Transparency Initiative in 2013, showed that not all noted domestic enterprises are ready for transparent performance (EITI, 2013).

Currently Ukraine is weakly characterized with integration into international scientific-technical and innovation cooperation, that's why an important issue of international partnership is the realization of the innovative principle which promotes the creation and dissemination of the mechanisms of cooperation in the field of innovation. Common technology park in Ukraine does not allow to create and implement innovative potential in the country. In this direction, forms of partnership in the innovation system which successfully operate in the EU, should be considered, including European innovation partnership, European technology platforms, contractual and institutionalized public-private partnerships, cluster-network structures of the European Institute of Innovation and Technology, European Industrial Initiatives, public partnerships (Khaustova V., 2015).

Summarizing the experience of partnership principles usage in practice allowed to make their estimate in gas sector. The estimate was carried out, taking into account not only partnership in sectoral integration within the national economy, but external signs of partnership as well (Table. 1). The estimate was done due to the scale of paired comparisons (T. Saati).

Table 1. - Estimate of partnership principles on national and international levels

\begin{tabular}{|c|c|c|}
\hline \multirow{2}{*}{ Principles } & \multicolumn{2}{|c|}{ Estimate } \\
\cline { 2 - 3 } & $\begin{array}{c}\text { National } \\
\text { level }\end{array}$ & $\begin{array}{c}\text { International } \\
\text { level }\end{array}$ \\
\hline 1.1 corporate management & 7 & 8 \\
\hline 1.2 innovation & 3 & 9 \\
\hline 1.3 integration & 6 & 8 \\
\hline 2.1 international trade & 3 & 8 \\
\hline $\begin{array}{c}\text { 2.2 compliance with technical } \\
\text { conditions }\end{array}$ & 3 & 6 \\
\hline 2.3 transparency & 4 & 6 \\
\hline 3.1 business and management & 5 & 7 \\
\hline 3.2 market economy & 4 & 7 \\
\hline 3.3 contract activity & 5 & 9 \\
\hline 4.1 balanced development & 3 & 5 \\
\hline 4.2 flexibility and adaptiveness & 3 & 5 \\
\hline 4.3 feedback & 5 & 7 \\
\hline
\end{tabular}

Due to the results of pairwise elements comparisons of the set $Q$ we construct a matrix of pairwise comparisons $A_{1}^{y}$, a random element of which is a measure of relative predominance of the element qi compared to the element qj for the first alternatives (national level). It is obvious that $a_{i i}=1$ and $a_{i j}=1 / a_{j i}$ for all $i, j=\overline{1, k}$.

$A_{1}^{y}=\left(\begin{array}{llllllllllll}7 & 7 / 3 & 7 / 6 & 7 / 3 & 7 / 3 & 7 / 4 & 7 / 5 & 7 / 4 & 7 / 5 & 7 / 3 & 7 / 3 & 3 / 5 \\ 6 & 6 / 3 & 1 & 6 / 3 & 6 / 3 & 6 / 4 & 6 / 5 & 6 / 4 & 6 / 5 & 6 / 3 & 6 / 3 & 6 / 5 \\ 3 & 3 / 3 & 3 / 6 & 1 & 3 / 3 & 3 / 4 & 3 / 5 & 3 / 4 & 3 / 5 & 3 / 3 & 3 / 3 & 3 / 5 \\ 3 & 3 / 3 & 3 / 6 & 3 / 3 & 1 & 3 / 4 & 3 / 5 & 3 / 4 & 3 / 5 & 3 / 3 & 3 / 3 & 3 / 5 \\ 4 & 4 / 3 & 4 / 6 & 4 / 3 & 4 / 3 & 1 & 4 / 5 & 4 / 4 & 4 / 5 & 4 / 3 & 4 / 3 & 4 / 5 \\ 5 & 5 / 3 & 5 / 6 & 5 / 3 & 5 / 3 & 5 / 4 & 1 & 5 / 4 & 5 / 5 & 5 / 3 & 5 / 3 & 5 / 5 \\ 4 & 4 / 3 & 4 / 6 & 4 / 3 & 4 / 3 & 4 / 4 & 4 / 5 & 1 & 4 / 5 & 4 / 3 & 4 / 3 & 4 / 5 \\ 5 & 5 / 3 & 5 / 6 & 5 / 3 & 5 / 3 & 5 / 4 & 5 / 5 & 5 / 4 & 1 & 5 / 3 & 5 / 3 & 5 / 5 \\ 3 & 3 / 3 & 3 / 6 & 3 / 3 & 3 / 3 & 3 / 4 & 3 / 5 & 3 / 4 & 3 / 5 & 1 & 3 / 3 & 3 / 5 \\ 3 & 3 / 3 & 3 / 6 & 3 / 3 & 3 / 3 & 3 / 4 & 3 / 5 & 3 / 4 & 3 / 5 & 3 / 3 & 1 & 3 / 5 \\ 5 & 5 / 3 & 5 / 6 & 5 / 3 & 5 / 3 & 5 / 4 & 5 / 5 & 5 / 4 & 5 / 5 & 5 / 3 & 5 / 3 & 1\end{array}\right)$


On the basis of the pairwise comparisons in matrix $A_{1}^{y}$ we construct normalized matrix $N_{1}$ by dividing each element $a_{i j}\left(i, j=\overline{1, k)}\right.$ on the amount of $j$-th column elements $S_{i}(j=\overline{1, k)}$.

$$
\begin{aligned}
& S_{1}=51 ; S_{2}=17 ; S_{3}=8,50 ; S_{4}=17 ; S_{5}=17 ; S_{6}=12,75 ; \\
& S_{7}=10,20 ; S_{8}=12,75 ; S_{9}=10,20 ; S_{10}=17 ; S_{11}=17 ; S_{12}=10,2 \\
& N_{1}=\left(\begin{array}{llllllllllll}
0,14 & 0,14 & 0,14 & 0,14 & 0,14 & 0,14 & 0,14 & 0,14 & 0,14 & 0,14 & 0,14 & 0,14 \\
0,06 & 0,06 & 0,06 & 0,06 & 0,06 & 0,06 & 0,06 & 0,06 & 0,06 & 0,06 & 0,06 & 0,06 \\
0,12 & 0,12 & 0,12 & 0,12 & 0,12 & 0,12 & 0,12 & 0,12 & 0,12 & 0,12 & 0,12 & 0,12 \\
0,06 & 0,06 & 0,06 & 0,06 & 0,06 & 0,06 & 0,06 & 0,06 & 0,06 & 0,06 & 0,06 & 0,06 \\
0,06 & 0,06 & 0,06 & 0,06 & 0,06 & 0,06 & 0,06 & 0,06 & 0,06 & 0,06 & 0,06 & 0,06 \\
0,08 & 0,08 & 0,08 & 0,08 & 0,08 & 0,08 & 0,08 & 0,08 & 0,08 & 0,08 & 0,08 & 0,08 \\
0,10 & 0,10 & 0,10 & 0,10 & 0,10 & 0,10 & 0,10 & 0,10 & 0,10 & 0,10 & 0,10 & 0,10 \\
0,08 & 0,08 & 0,08 & 0,08 & 0,08 & 0,08 & 0,08 & 0,08 & 0,08 & 0,08 & 0,08 & 0,08 \\
0,10 & 0,10 & 0,10 & 0,10 & 0,10 & 0,10 & 0,10 & 0,10 & 0,10 & 0,10 & 0,10 & 0,10 \\
0,06 & 0,06 & 0,06 & 0,06 & 0,06 & 0,06 & 0,06 & 0,06 & 0,06 & 0,06 & 0,06 & 0,06 \\
0,06 & 0,06 & 0,06 & 0,06 & 0,06 & 0,06 & 0,06 & 0,06 & 0,06 & 0,06 & 0,06 & 0,06 \\
0,10 & 0,10 & 0,10 & 0,10 & 0,10 & 0,10 & 0,10 & 0,10 & 0,10 & 0,10 & 0,10 & 0,10
\end{array}\right)
\end{aligned}
$$

Matrix $A_{1}^{y}$ is consistent, so it gets these weighted elements:

$$
\begin{aligned}
& u_{11}=0,14 u_{12}=0,06 ; u_{13}=0,12 ; u_{14}=0,06 ; u_{15}=0,06 ; u_{16}=0,08 ; \\
& u_{17}=0,10 ; u_{18}=0,08 ; u_{19}=0,10 ; u_{110}=0,06 ; u_{111}=0,06 ; u_{112}=0,10 ;
\end{aligned}
$$

Similarly, due to the results of pairwise comparisons of elements of the set $Q$ we construct the matrix of pairwise comparisons $A_{2}^{y}$ for the second alternative (international level).

$$
\begin{aligned}
A_{2}^{y}=\left(\begin{array}{llllllllllll}
8 & 8 / 9 & 8 / 8 & 8 / 8 & 8 / 9 & 8 / 6 & 8 / 7 & 8 / 7 & 8 / 9 & 8 / 5 & 8 / 5 & 8 / 7 \\
9 & 1 & 9 / 8 & 9 / 8 & 9 / 9 & 9 / 6 & 9 / 7 & 9 / 7 & 9 / 9 & 9 / 5 & 9 / 5 & 9 / 7 \\
8 & 8 / 9 & 1 & 8 / 8 & 8 / 9 & 8 / 6 & 8 / 7 & 8 / 7 & 8 / 9 & 8 / 5 & 8 / 5 & 8 / 7 \\
8 & 8 / 9 & 8 / 8 & 1 & 8 / 9 & 8 / 6 & 8 / 7 & 8 / 7 & 8 / 9 & 8 / 5 & 8 / 5 & 8 / 7 \\
9 & 9 / 9 & 9 / 8 & 9 / 8 & 1 & 9 / 6 & 9 / 7 & 9 / 7 & 9 / 9 & 9 / 5 & 9 / 5 & 9 / 7 \\
6 & 6 / 9 & 6 / 8 & 6 / 8 & 6 / 9 & 1 & 6 / 7 & 6 / 7 & 6 / 9 & 6 / 5 & 6 / 5 & 6 / 7 \\
7 & 7 / 9 & 7 / 8 & 7 / 8 & 7 / 9 & 7 / 6 & 1 & 7 / 7 & 7 / 9 & 7 / 5 & 7 / 5 & 7 / 7 \\
7 & 7 / 9 & 7 / 8 & 7 / 8 & 7 / 9 & 7 / 6 & 7 / 7 & 1 & 7 / 9 & 7 / 5 & 7 / 5 & 7 / 7 \\
9 & 9 / 9 & 9 / 8 & 9 / 8 & 9 / 9 & 9 / 6 & 9 / 7 & 9 / 7 & 1 & 9 / 5 & 9 / 5 & 9 / 7 \\
5 & 5 / 9 & 5 / 8 & 5 / 8 & 5 / 9 & 5 / 6 & 5 / 7 & 5 / 7 & 5 / 9 & 1 & 5 / 5 & 5 / 7 \\
5 & 5 / 9 & 5 / 8 & 5 / 8 & 5 / 9 & 5 / 6 & 5 / 7 & 5 / 7 & 5 / 9 & 5 / 5 & 1 & 5 / 7 \\
7 & 7 / 9 & 7 / 8 & 7 / 8 & 7 / 9 & 7 / 6 & 7 / 7 & 7 / 7 & 7 / 9 & 7 / 5 & 7 / 5 & 1
\end{array}\right) \\
S_{1}=85 ; S_{2}=9,44 ; S_{3}=10,63 ; S_{4}=10,63 ; S_{5}=9,44 ; S_{6}=14,17 ; S_{7}=12,14 ;
\end{aligned}
$$

On the basis of the matrix of pairwise comparisons $A_{2}^{y}$ we build normalized matrix $N_{2}$.

$$
N_{2}=\left(\begin{array}{llllllllllll}
0,09 & 0,09 & 0,09 & 0,09 & 0,09 & 0,09 & 0,09 & 0,09 & 0,09 & 0,09 & 0,09 & 0,09 \\
0,11 & 0,11 & 0,11 & 0,11 & 0,11 & 0,11 & 0,11 & 0,11 & 0,11 & 0,11 & 0,11 & 0,11 \\
0,09 & 0,09 & 0,09 & 0,09 & 0,09 & 0,09 & 0,09 & 0,09 & 0,09 & 0,09 & 0,09 & 0,09 \\
0,09 & 0,09 & 0,09 & 0,09 & 0,09 & 0,09 & 0,09 & 0,09 & 0,09 & 0,09 & 0,09 & 0,09 \\
0,11 & 0,11 & 0,11 & 0,11 & 0,11 & 0,11 & 0,11 & 0,11 & 0,11 & 0,11 & 0,11 & 0,11 \\
0,07 & 0,07 & 0,07 & 0,07 & 0,07 & 0,07 & 0,07 & 0,07 & 0,07 & 0,07 & 0,07 & 0,07 \\
0,08 & 0,08 & 0,08 & 0,08 & 0,08 & 0,08 & 0,08 & 0,08 & 0,08 & 0,08 & 0,08 & 0,08 \\
0,08 & 0,08 & 0,08 & 0,08 & 0,08 & 0,08 & 0,08 & 0,08 & 0,08 & 0,08 & 0,08 & 0,08 \\
0,07 & 0,07 & 0,07 & 0,07 & 0,07 & 0,07 & 0,07 & 0,07 & 0,07 & 0,07 & 0,07 & 0,07 \\
0,06 & 0,06 & 0,06 & 0,06 & 0,06 & 0,06 & 0,06 & 0,06 & 0,06 & 0,06 & 0,06 & 0,06 \\
0,06 & 0,06 & 0,06 & 0,06 & 0,06 & 0,06 & 0,06 & 0,06 & 0,06 & 0,06 & 0,06 & 0,06 \\
0,08 & 0,08 & 0,08 & 0,08 & 0,08 & 0,08 & 0,08 & 0,08 & 0,08 & 0,08 & 0,08 & 0,08
\end{array}\right)
$$

The matrix $A_{2}^{y}$ is consistent, so it gets these weighted elements:

$$
\begin{aligned}
& u_{21}=0,9 ; u_{22}=0,11 ; u_{23}=0,09 ; u_{24}=0,09 ; u_{25}=0,11 ; u_{26}=0,07 ; u_{27}=0,08 ; \\
& u_{28}=0,08 ; u_{29}=0,7 ; u_{210}=0,06 u_{211}=0,06 u_{212}=0,08
\end{aligned}
$$


Taking into account that the estimate of the state of partnership principles implementation depends largely on external factors, particularly in energy sector, the weighted coefficient of internal environment of partnership is taken as 0.45 , foreign - 0.55 . Multicriteria estimate of the importance of principles, discussed in the article, is as follows:

$$
\begin{aligned}
& U_{1}=w_{1} \cdot u_{11}+w_{2} \cdot u_{21}=0,45 \cdot 0,14+0,55 \cdot 0,9=0,063+0,495=0,558 \\
& U_{2}=w_{1} \cdot u_{12}+w_{2} \cdot u_{22}=0,45 \cdot 0,06+0,55 \cdot 0,11=0,027+0,055=0,082 \\
& U_{3}=w_{1} \cdot u_{13}+w_{2} \cdot u_{23}=0,45 \cdot 0,12+0,55 \cdot 0,09=0,054+0,05=0,104 \\
& U_{4}=w_{1} \cdot u_{14}+w_{2} \cdot u_{24}=0,45 \cdot 0,06+0,55 \cdot 0,9=0,027+0,495=0,522 \\
& U_{5}=w_{1} \cdot u_{15}+w_{2} \cdot u_{25}=0,45 \cdot 0,63+0,55 \cdot 0,11=0,284+0,061=0,345 \\
& U_{6}=w_{1} \cdot u_{16}+w_{2} \cdot u_{26}=0,45 \cdot 0,8+0,55 \cdot 0,07=0,044+0,039=0,083 \\
& U_{7}=w_{1} \cdot u_{17}+w_{2} \cdot u_{27}=0,45 \cdot 0,107+0,55 \cdot 0,08=0,048+0,044=0,092 \\
& U_{8}=w_{1} \cdot u_{18}+w_{2} \cdot u_{28}=0,45 \cdot 0,08+0,55 \cdot 0,08=0,036+0,044=0,08 \\
& U_{8}=w_{1} \cdot u_{18}+w_{2} \cdot u_{28}=0,45 \cdot 0,10+0,55 \cdot 0,07=0,045+0,055=0,1 \\
& U_{8}=w_{1} \cdot u_{18}+w_{2} \cdot u_{28}=0,45 \cdot 0,06+0,55 \cdot 0,06=0,027+0,033=0,06 \\
& U_{8}=w_{1} \cdot u_{18}+w_{2} \cdot u_{28}=0,45 \cdot 0,06+0,55 \cdot 0,06=0,027+0,033=0,06 \\
& U_{8}=w_{1} \cdot u_{18}+w_{2} \cdot u_{28}=0,45 \cdot 0,10+0,55 \cdot 0,08=0,045+0,046=0,091
\end{aligned}
$$

\begin{tabular}{|c|c|c|c|c|c|c|c|c|c|c|c|c|}
\hline \multirow[b]{2}{*}{ Estimate } & \multicolumn{12}{|c|}{ Partnership principles } \\
\hline & 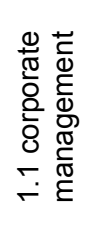 & 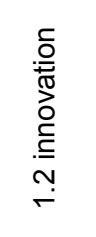 & 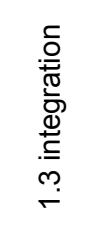 & 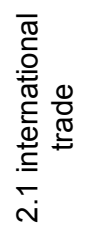 & 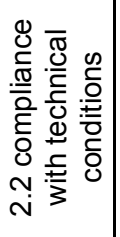 & 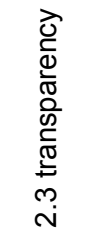 & 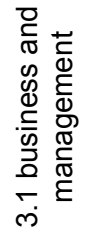 & 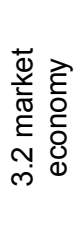 & 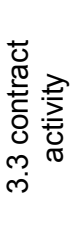 & 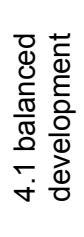 & 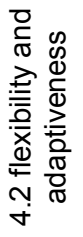 & 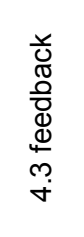 \\
\hline Value & 0,558 & 0,082 & 0,104 & 0,522 & 0,345 & 0,083 & 0,092 & 0,08 & 0,1 & 0,06 & 0,06 & 0,091 \\
\hline
\end{tabular}

Thus, the most significant principles of partnership in gas sector are: corporate management principles, principles of international trade, compliance with technical conditions, principle of integration, business and management, and contract activity (Table. 2).

Table 2. - Estimate of partnership principles nowadays in gas sector of energy sphere

Note: formed by the author on the basis of proposed method of estimate and validity of partnership principles in the development of gas field; significant parameters are calculated values which correspond with inequality $U_{i}=\frac{1}{12 \text { (parameters) }}>0,083$

Summarizing the results of international partnership principles research in gas sector, we can see that it has both theoretical and practical characteristics. Practical aspects are taken from expert reports and conclusions. Mathematical method of pairwise comparison of partnership principles on the basis of analyzed information highlights the majority of them. The weak point is that the research results are subjective, and the complexity of the issue does not allow to cover all problems of gas industry which touch partnership principles.

The research pays attention to the issues of industry transformation in the context of the development of gas industry, taking into account preconditions for international cooperation and partnership. Despite the fact that the implementation of partnership principles depends on many factors which need further research, the results describe some aspects of partnership that can serve as a guide for drawing attention to the areas of development.

Conclusions and directions of further researches

The category of energy partnerships appeared with the development of international cooperation in energy sector. We consider it as mutually beneficial form of cooperation among entities, individuals, government, public and nongovernmental organizations at international and national levels in matters of production, transportation, storage, distribution, energy consumption, as well as in matters related to energy consumption and energy efficiency, which require separate consideration. The importance of applying principles of international partnership lies in the creation of the experience of international activity in energy sector, particularly in meeting energy challenges, that Ukraine and the international community are facing, through the development of coherent, sustainable, competitive and secure energy policy and the establishment of stable, reliable and mutually beneficial partnership among the participants of energy market.

Thus, principles of international partnership and their implementation, particularly in the energy sector, have a great significance for the solution of contemporary problems in the activity of domestic enterprises due to: attracting additional resources to the development of a company and strengthening its development potential; increasing market share and capacity through performance diversification and involving partners; improvement or creation of the image of business partners; risk distribution among the sides in decision making process; compliance with the best standards of products and services quality as well as to the international legislation; experience gaining; improvement of products and enterprises competitiveness.

Further research might be directed to the analysis of partnership principles implementation in domestic enterprises activity in order to emphasize the obstacles of their development in cases of their involving to the international activity. 


\section{REFERENCES}

1. Brzezinski, Z. (2006). The choice: world domination or world leadership. Publishing house of Kyiv-Mohyla Academy, 2006.

2. Bauman, Z. (2008). Globalization. Consequences for an individual and the society. Publishing house of Kyiv-Mohyla Academy, 2006.

3. Bilorus, O., Vlasov, O. (2010). Globalistics - The new synthetic science. Bulletin of National Academy of Sciences of Ukraine. (3), pp. 17-26.

4. Lukyanenko, D., Kolesov, V., Kolot, A., Stolyarchuk, J. et al. (2013). Global economic development: trends, asymmetries, regulation: monograph. Publishing house of Kyiv National Economic University named by V. Hetman.

5. Voronkova, V. (2009). Formation of Postnonclassical modern management paradigm in globalization. Humanitarian Bulletin of Zaporozhye State Engineering Academy. (38), pp.13-29, available at: www.nbuv.gov.ua

6. Smith, A. (2007). An Inquity into the Nature and Causes of the Wealth of Nations. Edited by S. M. Soares. MetaLibri Digital Library, 2007, p. 27, available at: www.ibiblio.org

7. Kenigshteyn, I. (2015). Principles of genuine partnership, available at: www.ain.ua

8. European Strategy for Sustainable, Competitive and Secure Energy. Green book. (2006), available at: www.zakon2.rada.gov.ua.

9. Technical Regulation in the EU. (2016), available at: www.ukraine-eu.mfa.gov.ua.

10. Law of Ukraine "About natural gas market" (2015), available at: www. zakon4.rada.gov.ua.

11. Updated Energy Strategy of Ukraine until 2030 (2012), available at: www.mpe.kmu.gov.ua.

12. Krykavskiy, E., Chornopyska, N. (2012). Logistics systems. Publishing house of Lviv Polytechnic, 2012.

13. Krykavskiy, E., Chornopyska, N. (2013). "Logistics passport" of Ukraine in global competition. Management and Entrepreneurship in Ukraine: problems and stages of development. (769), pp. 324-331.

14. Chukhrai, N., Krivoruchko, Y. (2008). Research priorities in the formation of relationship among business partners. Actual problems of economy. (7), pp. 137-142.

15. Khaustova, V. (2015). Industrial Policy in Ukraine: formation and forecast: monograph. $384 \mathrm{p}$.

16. Dzoba, O., Romashko, O. (2012). Estimate of natural gas supply diversification in the European Union. Economic AnnalsXXI. Science journal. (7-8), pp. 37-40.
17. Zachmann, G., Naumenko, D. (2014). Estimate of options for gas supplies diversification to Ukraine. Institute of Economic Research and Political Consulting German Advisory Group Berlin, available at: www.ier.com.ua.

18. Annual report of The National Joint Stock Company "Naftogaz" of Ukraine (2015), available at: www.naftogaz.com.

19. Shevtsov, A., Zemlyanyy, M., Verbynskyy, V., Ryauzova, T. (2005). Diversification of gas supply to Ukraine. Desires and reality. Analytical note, available at: db.niss.gov.ua.

20. Initiative of transparency in extractive industries: summary, history of Ukraine. Report. (2013), available at: www.eiti.org.ua.

21. Ben, Gidley. (2012). Five principles of integration: policies and inclusion, available at: www.compas.ox.ac.uk.

22. Corrigan, Mary Beth, et al. (2005). Ten Principles for Successful Public, Private Partnerships, available at: www.uli.org.

23. Dudchenko, O. (2009). Energy priorities of Ukraine in the Black Sea region, available at: http://old.niss.gov.ua/Monitor/ october09/08.htm

24. Dedeluk. K. (2013). Prospects for Ukrainian transit infrastructure in the context of the EU energy consumption (2013). Vol. 2. pp. 135-141, available at: http://nbuv.gov.ua/UJRN/Vtneu_ 2013_2_17

25. Markevitch, K.V., Omelchenko, V. (2016). Pricing on energy markets: the experience of the EU and Ukraine. Analytical Report, Kyiv, $56 \mathrm{p}$.

26. Corporate Management of real sector companies in Ukraine (2016). available at: http://ibi.com.ua

27. Boytsun, A. (2014). Principles of corporate management in Ukrainian public enterprises: concept, available at: http:// naftogaz.com

28. Gas sector in Ukraine: options for separation of transportation and storage of natural gas, available at: http:// documents.worldbank.org/

29. Treaty about the establishment of Energy Community, available at: http://zakon2.rada.gov.ua/laws/show/994_926

30. The third Energy Package. (2012), available at: http:escoecosys.narod.ru.

31. Nasalyk, I. (2016). While implementing the Action Plan of the Government, Minenergovugillya is heading for openness and transparency, available at: http://mpe.kmu.gov.ua/ minugol/ control/ uk/publish/article.

32. Objectives, principles and areas of cooperation in energy sector // Institute of Economic Research and Political Consulting, available at: http://www.ier.com.ua

\section{Полянская Алла,}

доктор экономических наук, профессор,

Ивано-Франковский национальный технический университет нефти и газа,

Институт экономики и управления в нефтегазовом комплексе

\section{ПРИНЦИПЫ МЕЖДУНАРОДНОГО ПАРТНЕРСТВА В РАЗВИТИИ ОТЕЧЕСТВЕННЫХ ПРЕДПРИЯТИЙ}

В статье исследована сущность, характеристика и роль международного партнерства в развитии отечественных предприятий в условиях глобализации, особое внимание уделено формированию партнерских отношений в газовой отрасли. Обобщены принципы международного партнерства на национальном и международном уровнях. Определена значимость принципов международного партнерства в развитии газовой отрасли, и на основе проведенного оценивания опыта развития партнерских отношений в отрасли выделены направления деятельности, которые сегодня характеризуют результативность международного сотрудничества в ней. Проведенные исследования позволяют обосновать направления укрепления и расширения потенциала международного сотрудничества на основе реализации рассмотренных принципов международного партнерства.

Ключевые слова: международное партнерство; принципы; газовая отрасль; логистическая цепь; глобализация. 


\section{Полянська Алла,}

доктор економічних наук, професор,

Івано-Франківський національний технічний університет нафти $і$ газу,

Інститут економіки і управління у нафтогазовому комплексі

\section{ПРИНЦИПИ МІЖНАРОДНОГО ПАРТНЕРСТВА В РОЗВИТКУ ВІТЧИЗНЯНИХ ПІДПРИЕМСТВ}

У статті досліджено сутність, характеристику та роль міжнародного партнерства у розвитку вітчизняних підприємств в умовах глобалізації, особлива увага приділена формуванню партнерських відносин у газовій галузі. Узагальнено принципи міжнародного партнерства на національному та міжнародному рівнях. Визначено значимість принципів міжнародного підприємства в розвитку газової галузі та на основі проведенного оцінювання досвіду розвитку партнерських відносин у галузі виділено напрями діяльності, які на сьогодні характеризують результативність міжнародного співробітництва у галузі. Проведені дослідження дозволяють обґрунтувати напрями зміцнення та розширення потенціалу міжнародної співпраці на основі застосування розглянутих принципів міжнародного партнерства.

Ключові слова: міжнародне партнерство; принципи; газова галузь; логістичний ланцюг; глобалізація.

(C) Polyanska Alla

Надійшла до редакції 14.04.2017

УДК 332.122-043.86(477)

УСИК ІГОР,

здобувач, Донещький нац̧інальний університет імені Василя Стуса, м. Вінниия

\section{ТЕНДЕНЦІї ЕКОНОМІЧНОГО РОЗВИТКУ ТЕРИТОРІЙ УКРАЇНИ}

У статті визначено сучасний стан економічного розвитку територій України. Розглянуто валовий регіональний продукт, який є узагальнювальним показником економічної діяльності, результативності та характеризує новостворену вартість товарів і послуг, вироблених на певній території. Наведено географічну структуру розподілу валового регіонального продукту та виявлено його відмінності по регіонах України. Досліджено провідні області щодо виробництва найбільшої частки валового регіонального продукту. Проаналізовано види економічної діяльності деяких регіонів, виявлено динаміку зміни величини валового регіонального продукту в розрахунку на одну особу. Запропоновано напрямки збільшення валового регіонального продукту територій України, що забезпечить нові можливості та вигоди для областей та регіонів держави.

Ключові слова: регіони України; економічна діяльність; розвиток; господарство; показник; валовий регіональний продукт; динаміка; галузь; регіони; область.

Постановка проблеми. В умовах теперішніх змін світового господарства ключовими стають можливості створення дієвих механізмів вступу України в міжнародний політичний та економічний простір на основі використання регіональних моделей співробітництва. Стратегічною метою реалізації державної політики повинно бути створення умов для динамічного, збалансованого розвитку регіонів України з метою підвищення рівня їх конкурентоспроможності, активізації економічної діяльності, покращення рівня життя населення, забезпечення соціальних та економічних стандартів.

На сьогодні важливою передумовою забезпечення сталого зростання економіки, підвищення ефективності використання ресурсів є об'єктивне визначення рівня розвитку регіонального потенціалу.

Аналіз останніх досліджень і публікацій. Дослідженням основних проблем в області регіонального розвитку займаються вітчизняні та закордонні автори, зокрема О. Амоша [9], П. Гальчинський та Б. Данилишин [7], Ю. Зайцева [6], Ю. Макогон [9], М. Павловський [8], Ю. Стадницький [10], М. Чумаченко [9], О. Шаблій, М. М. Якубовський [5], Cameron C. Gordon [3], Hendrik Van den Berg [12], A. Pyka, J. Foster [13], Karen L. Higgins [14] та інші. Вони розглядають стратегічні питання розвитку територій у контексті сучасних умов господарювання, напрями й механізми їх вирішення, норматив- 